\title{
Electron-transfer complexation of morpholine donor molecule with some $\pi$ - acceptors: Synthesis and spectroscopic characterizations
}

\author{
Asma S. Al-Wasidi ${ }^{1 *}$, Nawal M. Al-Jafshar ${ }^{1}$, Amal M. Al-Anazi ${ }^{1}$, Eid H. Alosaimi², \\ Moamen S. Refat ${ }^{3,4}$, Lamia El-Zayat ${ }^{4}$, Mohamed A. Al-Omar ${ }^{5}$, Ahmed M. Naglah ${ }^{5,6}$, \\ Abou El-Nour K.M. ${ }^{7}$ \\ ${ }^{1}$ Department of Chemistry, College of Science, Princess Nourah Bint Abdulrahman University, Riyadh 11671, Saudi Arabia \\ ${ }^{2}$ Department of Chemistry, Faculty of Science, Bisha University, Bisha 61922, Saudi Arabia \\ ${ }^{3}$ Department of Chemistry, Faculty of Science, Taif University, Al-Haweiah, 21974, Taif, Saudi Arabia \\ ${ }^{4}$ Department of Chemistry, Faculty of Science, Port Said University, Port Said, 42521, Egypt \\ ${ }^{5}$ Drug Exploration and Development Chair (DEDC), Department of Pharmaceutical Chemistry, College of Pharmacy, \\ King Saud University, Riyadh 11451, Saudi Arabia \\ ${ }^{6}$ Peptide Chemistry Department, Chemical Industries Research Division, National Research Centre, 12622-Dokki, Cairo, Egypt \\ ${ }^{7}$ Chemistry Department, Faculty of Science, Suez Canal University, Ismailia, Egypt \\ "Corresponding authors: e-mail: asmachem7@hotmail.com
}

\begin{abstract}
Morpholine is an interesting moiety that used widely in several organic syntheses. The intermolecular charge-transfer (CT) complexity associated between morpholine (Morp) donor with (monoiodobromide "IBr", 2,3-dichloro-5,6dicyano-1,4-benzoquinone "DDQ", 2,6-dichloroquinone-4-chloroimide "DCQ" and 2,6-dibromoquinone-4-chloroimide "DBQ") $\pi$-acceptors have been spectrophotometrically investigated in $\mathrm{CHCl}_{3}$ and/or $\mathrm{MeOH}$ solvents. The structures of the intermolecular charge-transfer (CT) were elucidated by spectroscopic methods like, infrared spectroscopy. Also, different analyses techniques such as UV-Vis and elemental analyses were performed to characterize the four morpholine [(Morp)(IBr)], [(Morp)(DDQ)], [(Morp)(DCQ)] and [(Morp)(DBQ)] CT-complexes which reveals that the stoichiometry of the reactions is 1:1. The modified Benesi-Hildebrand equation was utilized to determine the physical spectroscopic parameters such as association constant $(\mathrm{K})$ and the molar extinction coefficient $(\varepsilon)$.
\end{abstract}

Keywords: Morpholine, $\pi$-acceptor, CT complex, photometric titration, infrared, Benesi-Hildebrand.

\section{INTRODUCTION}

Morpholine (Scheme 1) is an interesting moiety that used widely in several organic synthesis, also as a building block in the synthesis of antibiotic linezolid, and the anticancer agent ${ }^{1-3}$. The stable charge transfer complexes associated between some organic cyclic compounds as donor e.g. polysulpher, polyamines and oxygen-nitrogen crown ethers with iodine acceptor were discussed spectrophotometrically ${ }^{4-9}$.

The chemistry of donor-acceptor (CT) complexation has played a vital role in molecular systems and has turned into a center of attraction for various researchers ${ }^{10-14}$. This topic of interactions has gained great attention and considerable interest from chemists and pharmacists as well as biologists. The CT complexations have a broad range of applications not only in chemical and biological fields, but also in many technical and industrial ones. For example, they have been used in optical, electrical, solar energy storage, and magnetic conductivity applications, in studying pharmaceutical receptor binding mechanisms, and in biological applications ${ }^{15-18}$. Furthermore, CT complexations were used to obtain and develop simple, efficient, rapid and reliable methods for the determination, detection, or quantitative estimations of drugs in pure and pharmaceutical forms ${ }^{19,20}$. The thermal stabilities, crystallographic properties, and effects of several parameters, such as temperature, solvents, reagent concentration, and other parameters, on the properties and characteristics of the obtained CT products have also been intensively investigated and discussed $^{21-23}$.
In continuity of our experimental work in the trend of charge-transfer complexe ${ }^{24-30}$, herein the present article included the spectroscopic investigation of charge-transfer complexes of Morp with different acceptors ( $\sigma$ and $\pi$ ). The physical spectroscopic paramenters (association constants "K", molar extinction coefficient " $\varepsilon$ ", oscillator strength " $f$ " were calculated based on the spectrophotometric analyses. The isolated solid complexes were prepared and well characterized by elemental analysis, infrared, and UV-Vis electronic spectra.

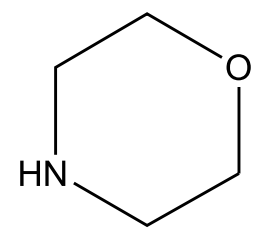

Scheme 1. Structure of Morpholine (I)

\section{EXPERIMENTAL}

\section{Chemical materials}

Chemicals used throughout this article were of pure grade. Morphiline was received from Merck Co. and the acceptors were received from Aldrich Co. The standard solutions of both Morp or of acceptors were freshly prepared in chloroform and methanol solvents.

\section{2-2-Synthesis of morphiline monoidobromide CT complex}

This dark brown solid charge transfer complex has a general formula, [(Morp)(IBr)]. It was synthesized by a mixing of $1 \mathrm{mmol}$ of Morp in $10 \mathrm{~mL} \mathrm{CHCl}$ with $1 \mathrm{mmol}$ of $\mathrm{IBr}$ in the same solvent with stirring for 15 
min at room temperature. The mixture solution was allowed to evaporate slowly at room temperature. The solid complex was formed, washed three times with little amounts of chloroform and dried under vacuum over anhydrous $\mathrm{CaCl}_{2}$.

\section{2-3-Synthesis of morphiline p-acceptors (DDQ, DCQ and DBQ) CT complexes}

The brown solid charge-transfer complexes of [(Morp) (DDQ)], [(Morp)(DCQ)] and [(Morp)(DBQ)] were synthesized by mixing $1 \mathrm{mmol}$ of Morp dissolved in 10 $\mathrm{mL}$ of $\mathrm{CHCl}_{3}$ with $1 \mathrm{mmol}$ of each p-acceptors (DDQ, DCQ and DBQ) in $10 \mathrm{~mL} \mathrm{CHCl}_{3}$ solvent with stirring for $15 \mathrm{~min}$ at room temperature. The solid precipitate associated in each case was filtered and washed three times with few drops of $\mathrm{CHCl}_{3}$ and dried under vacuo over anhydrous $\mathrm{CaCl}_{2}$.

\section{2-4-Instrumentals and physical measurements}

Electronic spectra were scanned using a Jenway 6405 Spectrophotometer within $200-800 \mathrm{~nm}$ region. In case of photometric titration measurements the concentrations of Morp donor was kept fixed at $5.0 \times 10^{-4} \mathrm{M}$, while the concentration of acceptors were ranged from $0.25 \times 10^{-4}$ to $4 \times 10^{-4} \mathrm{M}$, so the molar ratio between donor: acceptor is 1:0.25 to 1:4.00. Infrared measurements were performed on a Bruker FT-IR spectrophotometer $\left(400-4000 \mathrm{~cm}^{-1}\right)$.

\section{RESULTS AND DISCUSSION}

The microanalytical data of the synthesized solid CT complexes of morphiline with IBr, DDQ, DCQ and DBQ acceptors along with their physical properties are summarized in Table 1.

UV-Vis electronic spectra of chemical reactions between (IBr, DDQ, DCQ and DBQ) acceptors and Morp donor in solvents $\mathrm{CHCl}_{3}$ or $\mathrm{CH}_{3} \mathrm{OH}$ (Figs. $1 \mathrm{~A}-\mathrm{D}$ ) displayed distinguish charge transfer bands at 263, $373 \mathrm{~nm}$ for Morp-IBr, (401, $553 \mathrm{~nm}$ for Morp-DDQ, $320 \mathrm{~nm}$ for Morp-DCQ and 300, $396 \mathrm{~nm}$ for Morp-DBQ electron transfer systems, these CT bands don't belong to any of both acceptors and Morp. Photometric titrations between Morp donor and respected p-acceptors were operated at selected maximum CT bands mentioned above, when the concentration of Morp donor was prepared at $0.50 \times 10^{-4}$ $\mathrm{M}$, while the concentration of the ( $\mathrm{IBr}$ and $\mathrm{DDQ}$ ) acceptors was prepared within the range of $0.125 \times 10^{-4}$ $-1.50 \times 10^{-4} \mathrm{M}$. In case of DCQ and DBQ acceptors, the concentration of Morph donor is prepared with $0.250 \times 10^{-4} \mathrm{M}$, while the acceptors concentration was ranged between $0.0625 \times 10^{-4}-0.7500 \times 10^{-4} \mathrm{M}$. The $1: 1$ stoichiometric ratio of CT complex systems (Figs. 2 A-D) was performed using well known method $^{31}$. The association constant " $\mathrm{K}$ " and molar extinction coefficients "e" of the CT complex systems were calculated based on the 1:1 modified Benesi-Hildebrand equation $(1)^{32}$.

$\frac{C_{a}^{o} C_{d}^{o} l}{A}=\frac{1}{K \varepsilon}+\frac{C_{a}^{o}+C_{d}^{o}}{\varepsilon}$

Where and are the initial concentrations of the acceptors and Morp donor, respectively, and " $A$ " term is the absorbance of the distinguish CT bands. Straight lines Figs. $3 \mathrm{~A}-\mathrm{D}$ were obtained by drawing the $\left(C_{a}^{o} C_{d}^{o} / \mathrm{A}\right)$ term against

$\left(C_{a}^{o}+C_{d}^{o}\right)$ term. From these straight lines the slope $(1 / \mathrm{e})$ and intercept $(1 / \mathrm{Ke})$ for the $\mathrm{CT}$ reaction mixtures of Morp with p-acceptors in $\mathrm{CHCl}_{3}$ or $\mathrm{CH}_{3} \mathrm{OH}$ were calculated. The physical spectroscopic data $(\mathrm{K}, \mathrm{e}$, oscillator strength $(f)^{33}$ and transition dipole moment $(\mu)$ of the synthesized charge transfer complexes [(Morp) (IBr)], [(Morp)(DDQ)], [(Morp)(DCQ)] and [(Morp) (DBQ)] were calculated and summarized in Table $2^{\mathbf{3 4}}$. The charge transfer energy of the $n-\pi^{*}$ interaction was calculated as $3.33 \mathrm{eV}$ (IBr), $2.25 \mathrm{eV}$ (DDQ), $3.89 \mathrm{eV}$ (DCQ) and $3.14 \mathrm{eV}(\mathrm{DBQ})^{35}$. The ionization potential $\left(I_{p}\right)$ of the free donor of the highest filled molecular orbital was calculated from the CT energies of the CT band ${ }^{36-38}$. Photometric titrations reveal that the stoichiometry of the reaction mixtures is $1: 1$ which agree with the elemental analysis data of the isolated solid CT-complexes (Table 1).

Infrared spectra of the Morp charge transfer complexes of IBr, DDQ, DCQ and DBQ are illustrated in Figs. 4 A-D and their assignments are listed in Table 3. The outcome data resulted by make a comparison between the infrared of the Morp donor, acceptors (IBr,

Table 1. Elemental analysis and physical data of the synthesized Morp CT complexes

\begin{tabular}{|c|c|c|c|c|c|c|c|c|c|}
\hline \multirow{2}{*}{$\begin{array}{l}\text { Complexes/ } \\
\text { FW }\end{array}$} & \multirow{2}{*}{ Mwt } & \multicolumn{2}{|c|}{$\mathrm{C} \%$} & \multicolumn{2}{|c|}{$\mathrm{H} \%$} & \multicolumn{2}{|c|}{ N\% } & \multicolumn{2}{|c|}{ Physical data } \\
\hline & & Found & Calc. & Found & Calc. & Found & Calc. & Color & $\mathrm{Mp} /{ }^{\circ} \mathrm{C}$ \\
\hline $\begin{array}{l}\text { [(Morp)(IBr)] } \\
\left(\mathrm{C}_{4} \mathrm{H}_{9} \mathrm{NOIBr}\right)\end{array}$ & 293.93 & 16.11 & 16.30 & 2.95 & 3.06 & 4.65 & 4.76 & yellow & 54 \\
\hline $\begin{array}{l}\text { [(Morp)(DDQ)] } \\
\left(\mathrm{C}_{12} \mathrm{H}_{9} \mathrm{~N}_{3} \mathrm{Cl}_{2} \mathrm{O}_{3}\right) \\
\end{array}$ & 314.13 & 45.44 & 45.80 & 2.74 & 2.87 & 13.21 & 13.40 & brown & $<30$ \\
\hline $\begin{array}{l}\text { [(Morp)(DCQ)] } \\
\left(\mathrm{C}_{10} \mathrm{H}_{11} \mathrm{~N}_{2} \mathrm{Cl}_{3} \mathrm{O}_{2}\right)\end{array}$ & 297.57 & 40.12 & 40.30 & 3.68 & 3.70 & 9.35 & 9.41 & brown & $<30$ \\
\hline $\begin{array}{l}\text { [(Morp)(DBQ)] } \\
\left(\mathrm{C}_{10} \mathrm{H}_{11} \mathrm{~N}_{2} \mathrm{Br}_{2} \mathrm{ClO}_{2}\right)\end{array}$ & 386.49 & 30.58 & 31.00 & 2.80 & 2.85 & 7.11 & 7.24 & brown & $<30$ \\
\hline
\end{tabular}

Table 2. Physical Spectroscopic data of the Morp CT complexes

\begin{tabular}{|c|c|c|c|c|c|c|c|}
\hline Solvent & $\begin{array}{c}\lambda_{\max } \\
{[\mathrm{nm}]}\end{array}$ & $\begin{array}{c}\mathrm{E}_{\mathrm{CT}} \\
{[\mathrm{eV}]}\end{array}$ & $\begin{array}{c}\mathrm{K} \\
{\left[\mathrm{l} \cdot \mathrm{mol}^{-1}\right]}\end{array}$ & $\begin{array}{c}\varepsilon_{\max } \\
{\left[\mathrm{l} \cdot \mathrm{mol}^{-1} \cdot \mathrm{cm}^{-1}\right]}\end{array}$ & $f$ & $\mu$ & $\mathrm{I}_{\mathrm{p}}$ \\
\hline $\mathrm{IBr}$ & 373 & 3.33 & $2.16 \times 10^{4}$ & $1.78 \times 10^{4}$ & 12.00 & 30.90 & 7.44 \\
\hline $\mathrm{DDQ}$ & 553 & 2.25 & $8.34 \times 10^{4}$ & $1.81 \times 10^{4}$ & 9.77 & 33.90 & 8.51 \\
\hline $\mathrm{DCQ}$ & 320 & 3.88 & $4.76 \times 10^{4}$ & $3.58 \times 10^{4}$ & 21.50 & 38.20 & 7.83 \\
\hline $\mathrm{DBQ}$ & 396 & 3.14 & $4.25 \times 10^{4}$ & $2.77 \times 10^{4}$ & 12.50 & 32.40 & 7.31 \\
\hline
\end{tabular}


(A)

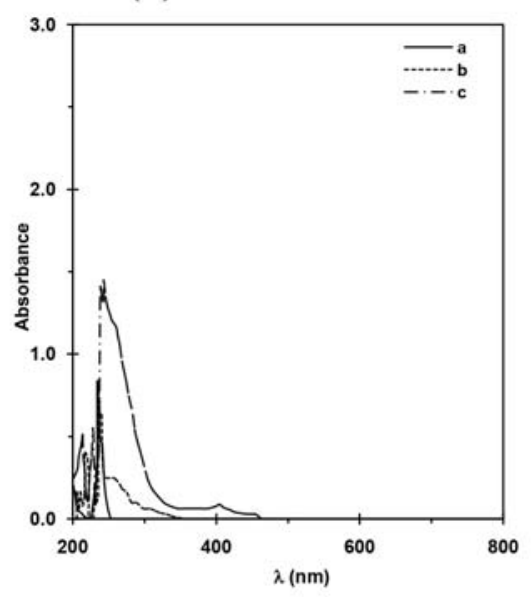

(C)

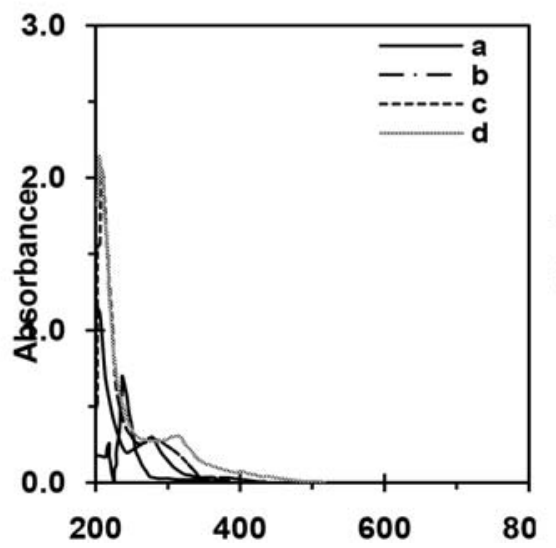

(B)

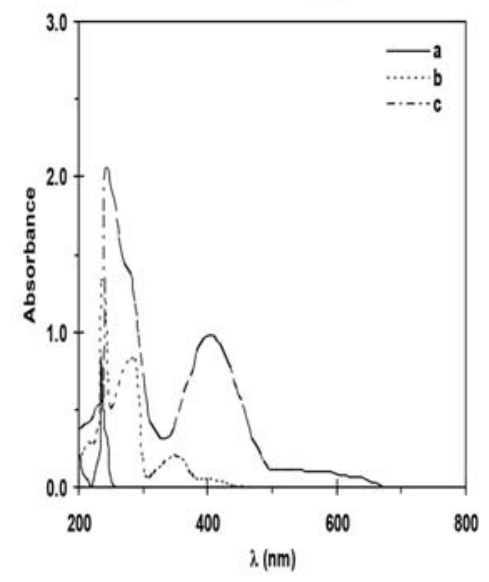

(D)

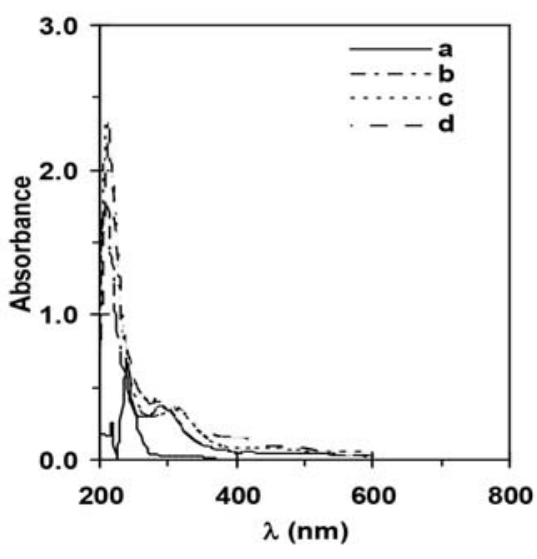

Figure 1. Electronic absorption spectra of (A): $\mathrm{Morp} / \mathrm{IBr}$ system in $\mathrm{CHCl}_{3}$, (B): Morp/DDQ system in $\mathrm{CHCl}$, $(\mathrm{C})$ : $\mathrm{Morp} / \mathrm{DCQ}$ system in $\mathrm{CH}_{3} \mathrm{OH}$ and (D): Morp/DBQ system in $\mathrm{CH}_{3} \mathrm{OH}\left(\mathrm{a}=\right.$ donor $\left(1.0 \times 10^{-4} \mathrm{M}\right)$, b = acceptor $\left(1.0 \times 10^{-4} \mathrm{M}\right)$ and $\mathrm{c}=$ CT-complex)
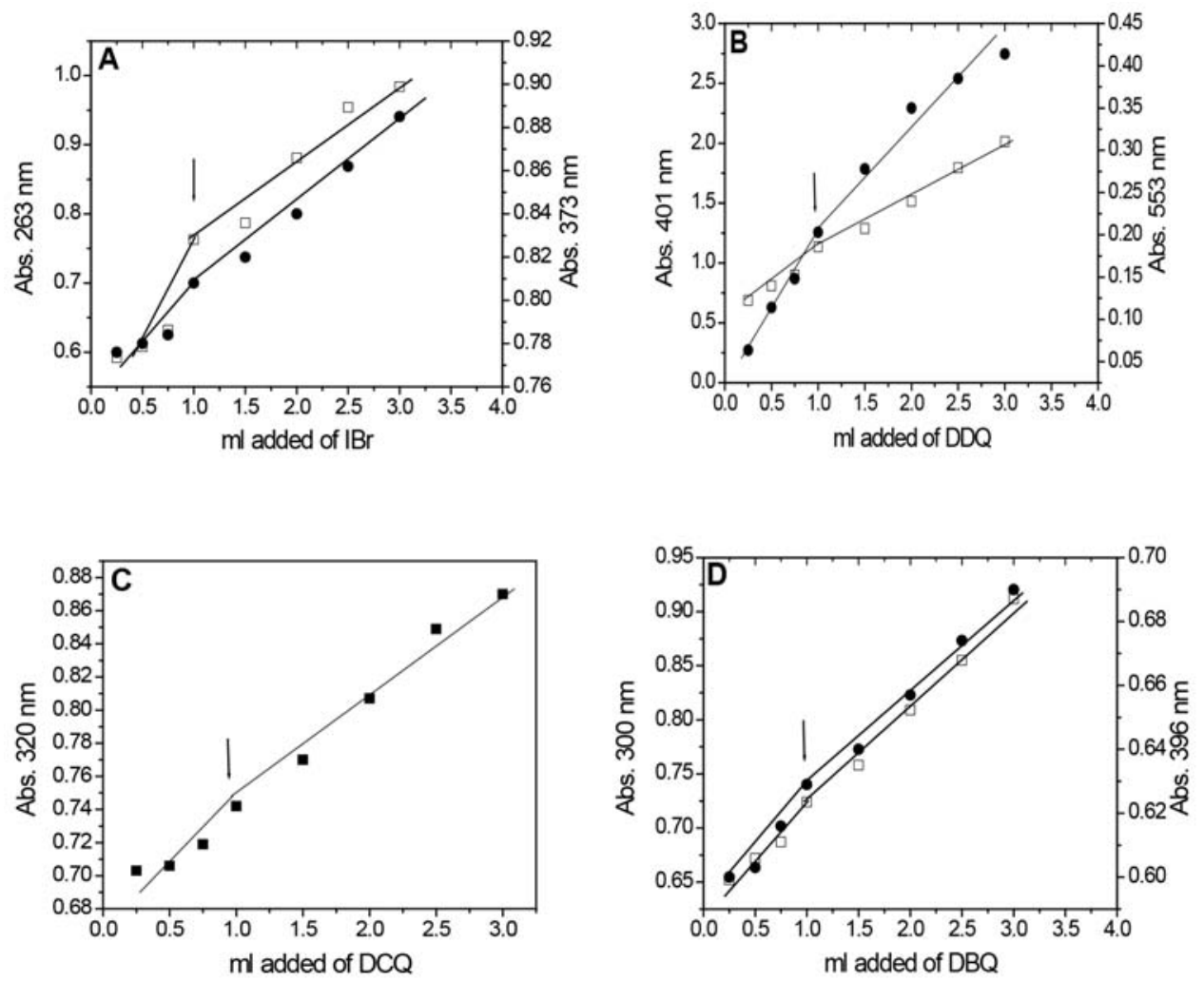

Figure 2. Photometric titration curves for: (A): Morp/IBr system in $\mathrm{CHCl}_{3}$ at 263 and $373 \mathrm{~nm}$, (B): $\mathrm{Morp}_{\mathrm{DDQ}}$ system in $\mathrm{CHCl}$ at 401 and $553 \mathrm{~nm},(\mathrm{C}):$ Morp/DCQ system in $\mathrm{CH}_{3} \mathrm{OH}$ at $320 \mathrm{~nm}$ and (D): Morp/DBQ system in $\mathrm{CH}_{3} \mathrm{OH}$ at $300 \mathrm{~nm}$ and $396 \mathrm{~nm}$ 

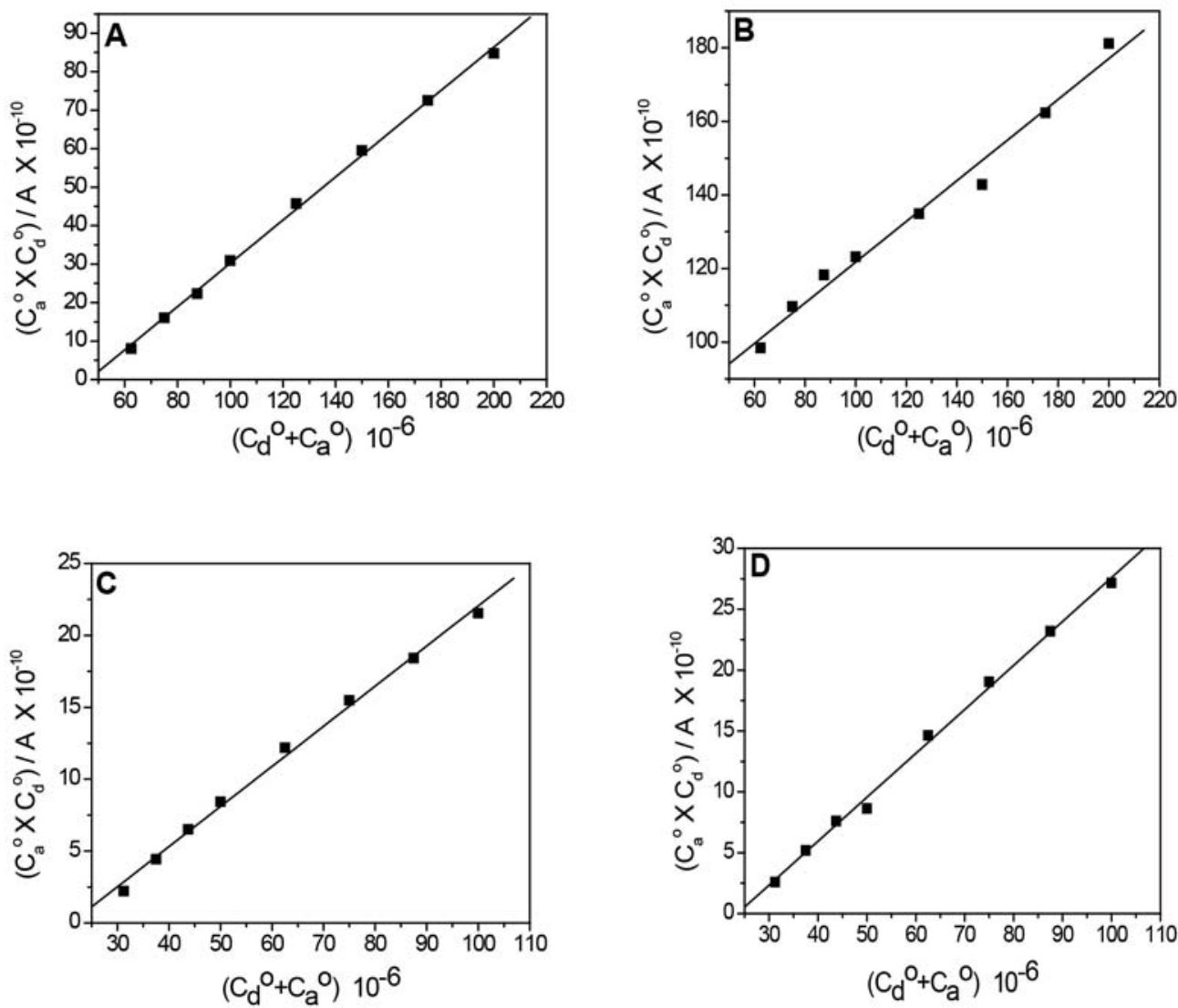

Figure 3. The plot of $\left(\mathrm{C}_{\mathrm{d}}{ }^{\mathrm{o}}+\mathrm{C}_{\mathrm{a}}{ }^{\circ}\right)$ values against $\left(\mathrm{C}_{\mathrm{d}}{ }^{\mathrm{o}} \cdot \mathrm{C}_{\mathrm{a}}{ }^{\mathrm{o}} / \mathrm{A}\right)$ values for: $(\mathrm{A})$ : Morp/IBr system in $\mathrm{CHCl}_{3}$ at $373 \mathrm{~nm}$, $(\mathrm{B})$ : $\mathrm{Morp} /$ DDQ system in $\mathrm{CHCl}_{3}$ at $553 \mathrm{~nm},(\mathrm{C})$ : Morp/DCQ system in $\mathrm{CH}_{3} \mathrm{OH}$ at $320 \mathrm{~nm}$ and (D): Morp/DBQ system in $\mathrm{CH}_{3} \mathrm{OH}$ at $396 \mathrm{~nm}$
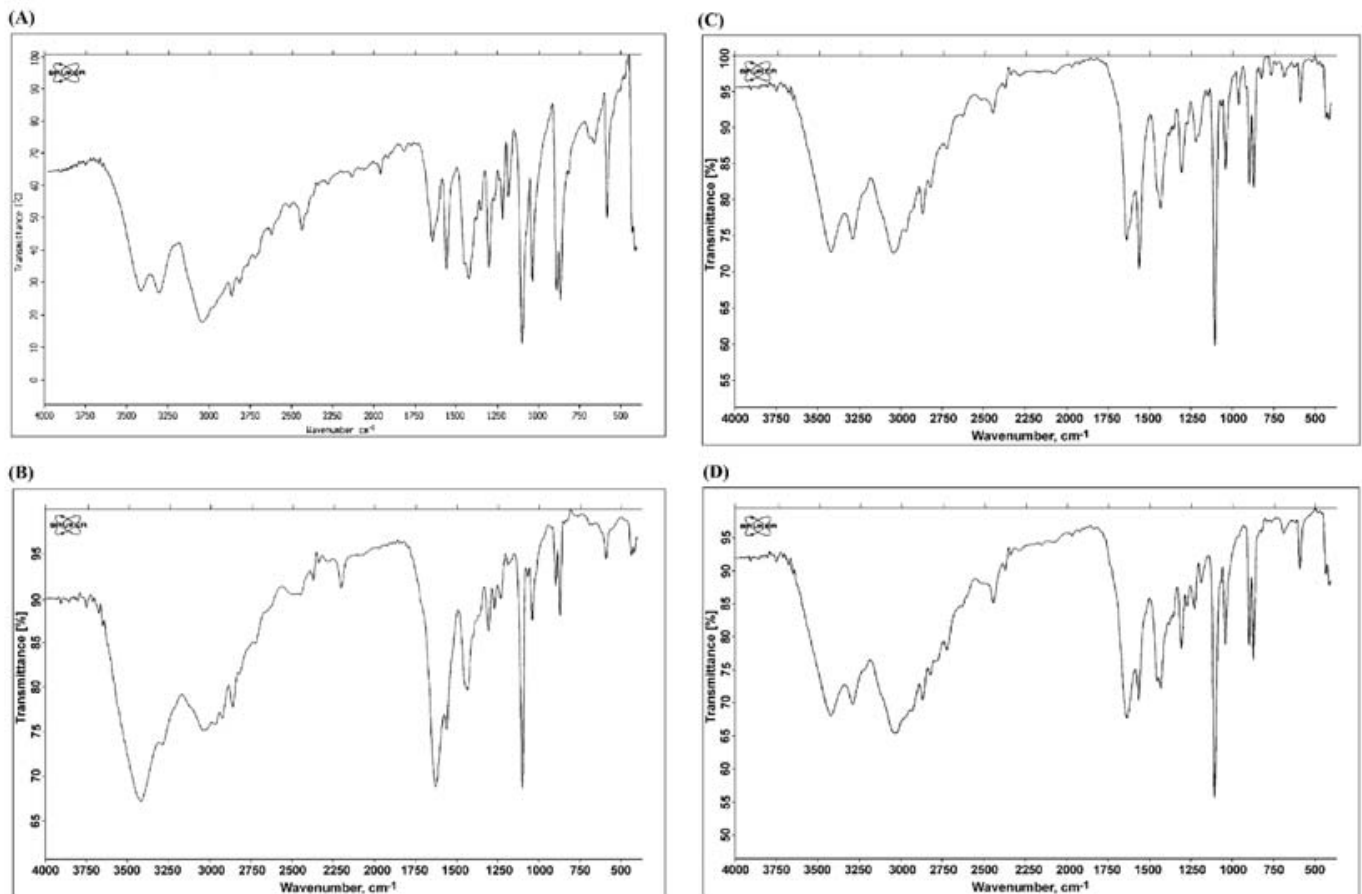

Figure 4. Infrared spectra of (A): [(Morp)(IBr)], (B): [(Morp)(DDQ)], (C): [(Morp)(DCQ)] and (D): [(Morp)(DBQ)] charge transfer complexes

DDQ, DCQ and DBQ) and isolated solid charge transfer complexes can be summarized as follows:

Concerning of [(Morp)(IBr)] complex, the stretching frequency $\mathrm{n}(\mathrm{N}-\mathrm{H})$ of the $-\mathrm{NH}$ Morp donor which was observed at 3424 and $3300 \mathrm{~cm}^{-1}$ is shifted to 3416 and $3306 \mathrm{~cm}^{-1}$ in case of CT complex. There are frequencies bands presence at 3044, 2863, 2816 and $2723 \mathrm{~cm}^{-1}$ due to $\mathrm{n}_{\mathrm{s}}(\mathrm{C}-\mathrm{H})$ and $\mathrm{n}_{\mathrm{as}}(\mathrm{C}-\mathrm{H})$ vibrations. These vibration bands were small shifted to higher wavenumbers with decreasing in the intensities compared with the Morp free donor. The new weak vibration bands observed at the range of $2600-2400 \mathrm{~cm}^{-1}$ for the IBr/Morp complex can be assigned to hydrogen bonding ${ }^{39}$. The vibrations bands of $\delta(\mathrm{N}-\mathrm{H}), \mathrm{n}(\mathrm{C}-\mathrm{N}), \mathrm{CNC}$ deformation show clearly 
Table 3. Infrared frequencies ${ }^{(a)}\left(\mathrm{cm}^{-1}\right)$ and tentative assignments for charge transfer Morp complexes

\begin{tabular}{|c|c|c|c|c|}
\hline \multicolumn{4}{|c|}{ [(Morp)(acceptor)] CT-complexes } & \multirow[t]{2}{*}{ Assignments $^{(\text {b) }}$} \\
\hline $\mathrm{IBr}$ & $\mathrm{DDQ}$ & $\mathrm{DCQ}$ & DBQ & \\
\hline $\begin{array}{l}3416 \mathrm{~ms} \\
3306 \mathrm{~ms}\end{array}$ & $\begin{array}{c}3423 \mathrm{~s}, \mathrm{br} \\
3307 \mathrm{w}\end{array}$ & $\begin{array}{l}3418 \mathrm{~s} \\
3288 \mathrm{~s}\end{array}$ & $\begin{array}{l}3418 \mathrm{~s} \\
3287 \mathrm{~s}\end{array}$ & $\begin{array}{c}v(\mathrm{O}-\mathrm{H}) ; \mathrm{H}_{2} \mathrm{O} \text { of } \mathrm{KBr} \\
v(\mathrm{~N}-\mathrm{H})\end{array}$ \\
\hline $\begin{array}{l}3044 \mathrm{~s}, \mathrm{br} \\
2863 \mathrm{w} \\
2816 \mathrm{vw} \\
2723 \mathrm{vw}\end{array}$ & $\begin{array}{l}3037 \mathrm{w}, \mathrm{br} \\
2975 \mathrm{vw} \\
2928 \mathrm{w} \\
2864 \mathrm{~ms} \\
2750 \mathrm{vw} \\
\end{array}$ & $\begin{array}{l}3042 \mathrm{~s}, \mathrm{br} \\
2950 \mathrm{vw} \\
2912 \mathrm{vw} \\
2866 \mathrm{~ms} \\
2821 \mathrm{vw}\end{array}$ & $\begin{array}{c}3032 \mathrm{~s}, \mathrm{br} \\
2865 \mathrm{~ms} \\
2819 \mathrm{w}\end{array}$ & $v_{s}(C-H)+v_{a s}(C-H)$ \\
\hline $\begin{array}{l}2624 \mathrm{vw} \\
2514 \mathrm{vw} \\
2439 \mathrm{~ms}\end{array}$ & $\begin{array}{l}2712 \mathrm{vw} \\
2625 \mathrm{w} \\
2448 \mathrm{~ms}\end{array}$ & $\begin{array}{l}2724 \mathrm{w} \\
2625 \mathrm{vw} \\
2444 \mathrm{~ms}\end{array}$ & $\begin{array}{l}2719 \mathrm{w} \\
2630 \mathrm{vw} \\
2442 \mathrm{~ms}\end{array}$ & Hydrogen bonding \\
\hline. & $2202 \mathrm{~ms}$ & - & - & $v(\mathrm{C} \equiv \mathrm{N}) ; \mathrm{DDQ}$ \\
\hline- & 1632 vs & - & - & $v(\mathrm{C}=\mathrm{O})+v(\mathrm{C}=\mathrm{N}) ; \quad \mathrm{DDQ}, \mathrm{DCQ}$ and $\mathrm{DBQ}$ \\
\hline $1645 \mathrm{~s}$ & 1623 vs & $1637 \mathrm{~s}$ & $1633 \mathrm{~s}$ & $\begin{array}{c}\delta_{\text {def }}(\mathrm{N}-\mathrm{H}) \\
\text { Ring breathing bands }\end{array}$ \\
\hline $\begin{array}{l}1560 s \\
1423 s\end{array}$ & $\begin{array}{c}1564 \mathrm{~ms} \\
1437 \mathrm{~s}\end{array}$ & $\begin{array}{l}1561 \mathrm{vs} \\
1432 \mathrm{~s}\end{array}$ & $\begin{array}{c}1562 \mathrm{~s} \\
1450 \mathrm{vw} \\
1420 \mathrm{w} \\
\end{array}$ & $\begin{array}{c}v(\mathrm{C}=\mathrm{C}) ; \mathrm{DDQ}, \mathrm{DCQ} \text { and } \mathrm{DBQ} \\
\mathrm{C}-\mathrm{H} \text { deformation }\end{array}$ \\
\hline $\begin{array}{c}1351 \mathrm{vw} \\
1303 \mathrm{~s} \\
1220 \mathrm{~ms} \\
1185 \mathrm{~s} \\
1101 \mathrm{vs} \\
1039 \mathrm{~s}\end{array}$ & $\begin{array}{c}1308 \mathrm{~ms} \\
1272 \mathrm{mw} \\
1234 \mathrm{mw} \\
1188 \mathrm{w} \\
1105 \mathrm{vs} \\
1069 \mathrm{w} \\
1041 \mathrm{~ms} \\
\end{array}$ & $\begin{array}{c}1357 \mathrm{vw} \\
1307 \mathrm{~s} \\
1222 \mathrm{~s} \\
1150 \mathrm{vw} \\
1104 \mathrm{vs} \\
1068 \mathrm{vw} \\
1042 \mathrm{~s} \\
\end{array}$ & $\begin{array}{c}1306 \mathrm{~s} \\
1273 \mathrm{w} \\
1228 \mathrm{~ms} \\
1188 \mathrm{~ms} \\
1103 \mathrm{vs} \\
1041 \mathrm{~s}\end{array}$ & $\begin{array}{c}v(\mathrm{C}-\mathrm{C})+v(\mathrm{C}-\mathrm{N})+v(\mathrm{C}-\mathrm{O}-\mathrm{C}) \\
\mathrm{CH}, \text { in-plane bend }\end{array}$ \\
\hline $\begin{array}{l}892 \mathrm{~s} \\
869 \mathrm{~s} \\
819 \mathrm{vw}\end{array}$ & $\begin{array}{l}898 \mathrm{~ms} \\
872 \mathrm{~s} \\
846 \mathrm{vw}\end{array}$ & $\begin{array}{l}964 \mathrm{~s} \\
887 \mathrm{~s} \\
872 \mathrm{~s} \\
828 \mathrm{w} \\
770 \mathrm{w} \\
\end{array}$ & $\begin{array}{l}897 \mathrm{~s} \\
871 \mathrm{~s} \\
791 \mathrm{vw}\end{array}$ & $\begin{array}{c}\delta_{\text {rock }} ; \mathrm{NH} \\
\mathrm{CH} \text {-deformation } \\
v(\mathrm{C}-\mathrm{Cl})+v(\mathrm{C}-\mathrm{Br}) ; \mathrm{DDQ}, \mathrm{DCQ} \text { and } \mathrm{DBQ}\end{array}$ \\
\hline $\begin{array}{l}665 \mathrm{~m} \\
586 \mathrm{vs}\end{array}$ & $592 \mathrm{~ms}$ & $\begin{array}{l}690 \mathrm{w} \\
630 \mathrm{vw} \\
593 \mathrm{~s}\end{array}$ & $\begin{array}{l}691 \mathrm{~ms} \\
593 \mathrm{~s}\end{array}$ & $\begin{array}{l}\text { skeletal vibration } \\
\mathrm{CH} \text { bend }\end{array}$ \\
\hline $\begin{array}{l}432 \mathrm{vw} \\
414 \mathrm{~s}\end{array}$ & $\begin{array}{l}439 \mathrm{vw} \\
421 \mathrm{vw}\end{array}$ & $\begin{array}{l}487 v w \\
462 v w \\
437 v w \\
420 v w \\
\end{array}$ & $\begin{array}{l}437 \mathrm{vw} \\
415 \mathrm{w}\end{array}$ & $\begin{array}{l}\mathrm{CH} \text { out of plane bend } \\
\text { Skeletal vibration } \\
\text { CNC def. }\end{array}$ \\
\hline
\end{tabular}

(a): $\mathrm{s}=$ strong, $\mathrm{w}=$ weak $\mathrm{m}=$ medium, $\mathrm{sh}=$ shoulder, $\mathrm{v}=$ very, $\mathrm{br}=$ broad.

(b): $v$, stretching; $\delta$, bending.

changes in comparable with free Morp donor (Table 3). This observation confirm that the charge transfer chelation between Morp and IBr takes place through the formation of hydrogen bonding between - NH group of morpholine and $\mathrm{IBr}$ acceptor (Scheme 2).

For the [(Morp)(DDQ)] CT complex, the infrared frequencies of both $\mathrm{n}(\mathrm{C} \equiv \mathrm{N})$ cyano group, $\mathrm{n}(\mathrm{C}=\mathrm{O})$ and $\mathrm{n}(\mathrm{C}-\mathrm{Cl})$ in case of complex are shifted to lower wavenumber values in comparison with free DDQ acceptor. The stretching vibration band of $\mathrm{n}(\mathrm{C} \equiv \mathrm{N})$ is occurred at 2250 and $2231 \mathrm{~cm}^{-1}$ in case of free DDQ acceptor, this bands were shifted to lower frequencies at $2202 \mathrm{~cm}^{-1}$ in case of charge transfer complex. While the $\mathrm{n}(\mathrm{C}=\mathrm{O})$ vibration band for the free DDQ is observed at 1673 $\mathrm{cm}^{-}$, this was shifted to lower value $1632 \mathrm{~cm}^{-1}$ in case of charge transfer complex. The new bands presence in case of charge transfer complex within the $2600-2400 \mathrm{~cm}^{-1}$ range are assigned to the association of hydrogen bonding through the deprotonation of $-\mathrm{NH}$ group of Morp to one of the CN groups of DDQ acceptor (Scheme 2).

Regarding the IR spectra of two [(Morp)(DCQ)] and $[($ Morp $)(\mathrm{DBQ})]$ charge transfer complexes, there are few weak bands at the range of $2400-2800 \mathrm{~cm}^{-1}$ which didn't present in the spectra of the reactants. These bands are assigned to the stretching vibration of hydrogen bonding ${ }^{39}$, which were formed through the $-\mathrm{NH}$ of Morp donor and the oxygen atom of the carbonyl group of acceptors (DCQ and DBQ). The stretching vibration bands of $\mathrm{n}(\mathrm{C}=\mathrm{O})$ group are located at 1696, 1686,1658 and $1656 \mathrm{~cm}^{-1}$ in case of the free acceptors. These bands are shifted to $1637 \mathrm{~cm}^{-1}$ in case of DCQ and at $1633 \mathrm{~cm}^{-1}$ for DBQ acceptor, respectively. This led to confirm that the carbonyl group is participated in the charge transfer complexation (Scheme 2).<smiles>NN1CCOCC1</smiles>

(A)

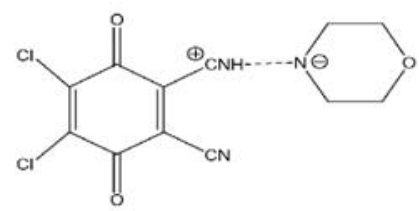

(B)<smiles>N#CC1=CC(C[18N]N2CCOCC2)C=C(Br)C1Br</smiles><smiles>N=C1C(Cl)=CC([18O]N2CCOCC2)C=C1Cl</smiles>

(C)

Scheme 2. Mode of charge transfer chelating of: (A): [(Morp)(IBr)], (B): [(Morp)(DDQ)], (C): [(Morp)(DCQ)] and [(Morp) (DBQ)] complexes 


\section{CONCLUSIONS}

Considerable attention and interest have been devoted to the chemistry of CT interactions especially with major moieties presence in many drugs. This interest is due to the potentially useful of the obtained products in a wide range of applications. The results reported in this paper are demonstrated the spectroscopic and structural studies of the CT products derived from the reaction of Morp donr which is an essential molecule in synthetic drugs with four acceptors (IBr, DDQ, DBQ and DCQ). The CT products were synthesized in $\mathrm{CHCl}_{3}$ solvent, isolated and characterized spectroscopically using UV-Vis and IR spectroscopy. Results obtained by elemental analysis and titrations confirmed that the reaction stoichiometry is 1:1, and the formed products has the general formula: [(Morp)(acceptor)]. The complexation between the donr and the acceptor was taking place by the formation of intermolecular hydrogen bond coupled.

\section{CONFLICT OF INTEREST}

The authors declare no potential conflicts of interest with respect to the research, authorship, and publication of this article.

\section{ACKNOWLEDGEMENTS}

This work was funded by the Deanship of Scientific Research at Princess Nourah bint Abdulrahman University, through the Research Groups Program Grant no. (RGP-1440-0003).

\section{LITERATURE CITED}

1. Behmadi, H., Moghaddam, Z.A., Poormorteza, N., Beyramabadi, S.A. \& Nezhad, M.A.A. (2017). A four Components, One-Pot Synthesis of New Imidazole Molecular Tweezers Based on 2,4,6-Triarylpyridine as Hinge Region. Iran. J. Chem. Chem. Eng. (IJCCE), 36(1), 11-17.

2. Weigelt, J., Itani, K., Stevens, D., Lau, W., Dryden, M., Knirsch, C. \& Group, L.C.S. (2005). Linezolid versus Vancomycin in Treatment of Complicated Skin and Soft Tissue Infections. Antimicrob. Agents. Chemother., 49(6), 2260-2266. DOI: 10.1128/AAC.49.6.2260-2266.2005.

3. McKeage, K. (2015). Finafloxacin: First Global Approval. Drugs, 75(6), 687-693. DOI://doi.org/10.1007/s40265-015-0384-z.

4. Mizuno, M., Tanaka, J. \& Harada, I. (1981). Electronic spectra and structures of polyiodide chain complexes. J. Phys. Chem., 85, 1789-1794. https://doi.org/10.1021/j150613a006.

5. Nour, E.M., Chen, L.H. \& Laane, J. (1986). Resonance Raman and far-infrared studies of charge-transfer complexes of iodine. J. Raman, Spectrosc., 17, 467-469. https://doi. org/10.1002/jrs.1250170608.

6. Nour, E.M., Chen, L.H. \& Laane, J. (1986). Far-infrared and Raman spectroscopic studies of polyiodides. J. Phys. Chem., 90, 2841-2846. https://doi.org/10.1021/j100404a014.

7. Mulazzi, E., Pollini, I., Piseri, L. \& Tubino, R. (1981). Selective resonant Raman enhancement in polyiodide chains. Phys. Rev., (B) 24, 3555-3563. DOI: https://doi.org/10.1103/ PhysRevB.24.3555.

8. Nour, E.M. (2000). Resonance Raman study of the polyiodide complex formed in the reaction of iodine with the polysulphur cyclic base 1,4,7,10,13,16-hexathiacyclooctadecane. Spectrochim. Acta., 56A, 167-170. https://doi.org/10.1016/ S1386-1425(99)00130-4.

9. Nour, E.M. \& Shahada, L.A. (1988). Electronic spectral studies and solvent effects on the reaction of iodine with 1,4,8,11-tetraazacyclotetradecane. Spectrochim. Acta., 44A, 1277-1280. https://doi.org/10.1016/0584-8539(88)80169-7.

10. Singh, N., Khan, I.M., Ahmad, A. \& Javed, S. (2014). Preparation, spectral investigation and spectrophotometric studies of proton transfer complex of 2,2'-bipyridine with 3,5-dinitrobenzoic acid in various polar solvents. J. Mol. Struct., 1065-1066, 74-85. https://doi.org/10.1016/j.molstruc.2014.02.017.

11. Khan, I.M., Shakya, S. \& Singh, N. (2018). Preparation, single-crystal investigation and spectrophotometric studies of proton transfer complex of 2,6-diaminopyridine with oxalic acid in various polar solvents. J. Mol. Liq., 250, 150-161. https:// doi.org/10.1016/j.molliq.2017.11.150.

12. Khan, I.M., Alam, K., Alam, M.J. \& Ahmad, M. (2019). Spectrophotometric and photocatalytic studies of H-bonded charge transfer complex of oxalic acid with imidazole: single crystal XRD, experimental and DFT/TD-DFT studies New J. Chem., 43, 9039-9051. DOI:10.1039/C9NJ00332K.

13. Khan, I.M. \& Shakya, S. (2019). Exploring Colorimetric Real-Time Sensing Behavior of a Newly Designed CT Complex toward Nitrobenzene and Co2+: Spectrophotometric, DFT/ TD-DFT, and Mechanistic Insights. ACS Omega, 4, 9983-9995. https://doi.org/10.1021/acsomega.9b01314.

14. Singh, N., Khan, I.M., Ahmad, A. \& Javed, S. (2016). Synthesis, spectrophotometric and thermodynamic studies of charge transfer complex of 5,6-dimethylbenzimidazole with chloranilic acid at various temperatures in acetonitrile and methanol solvents. J. Mol. Liq., 221, 1111-1120. https://doi. org/10.1016/j.molliq.2016.06.081.

15. Almalki, A.S.A., Alhadhrami, A., Adam, A.M.A., Grabchev, I., Almeataq, M., Al-Humaidi, J.Y., Sharshar, T. \& Refat, M.S. (2018). Preparation of elastic polymer slices have the semiconductors properties for use in solar cells as a source of new and renewable energy. J. Photochem. Photobiol., A 361, 76-85. https://doi.org/10.1016/j.jphotochem.2018.05.001.

16. Almalki, A.S.A., Alhadhrami, A., Obaid, R.J., Alsharif, M.A., Adam, A.M.A., Grabchev, I. \& Refat, M.S. (2018). Preparation of some compounds and study their thermal stability for use in dye sensitized solar cells. J. Mol. Liq. 261, 565-582. https://doi.org/10.1016/j.molliq.2018.04.057.

17. Datta, A.S., Bagchi, S., Chakrabortty, A. \& Lahiri, S.C. (2015). Studies on the weak interactions and CT complex formations between chloranilic acid, 2,3-dichloro-5,6-dicyano-p-benzoquinone, tetracyanoethylene and papaverine in acetonitrile and their thermodynamic properties, theoretically, spectrophotometrically aided by FTIR. Spectrochim. Acta A, 146, 119-128. https://doi.org/10.1016/j.saa.2015.02.064.

18. Saravanabhavan, M., Sathya, K., Puranik, V.G. \& Sekar, M. (2014). Synthesis, spectroscopic characterization and structural investigations of new adduct compound of carbazole with picric acid: DNA binding and antimicrobial studies. Spectrochim. Acta A, 118, 399-406. https://doi.org/10.1016/j.saa.2013.08.115.

19. Mohamed, M.E., Frag, E.Y.Z., Hathoot, A.A. \& Shalaby, E.A. (2018). Spectrophotometric determination of fenoprofen calcium drug in pure and pharmaceutical preparations. Spectroscopic characterization of the charge transfer solid complexes. Spectrochim. Acta A, 189, 357-365. https://doi.org/10.1016/j. saa.2017.08.027.

20. Shehab, O.R., AlRabiah, H., Abdel-Aziz, H.A. \& Mostafa, G.A.E. (2018). Charge-transfer complexes of cefpodoxime proxetil with chloranilic acid and 2,3-dichloro-5,6-dicyano-1,4-benzoquinone: Experimental and theoretical studies. J. Mol. Liq. 257, 42-51. https://doi.org/10.1016/j.molliq.2018.02.083.

21. Soltani, S., Magri, P., Rogalski, M. \& Kadri, M. (2019). Charge-transfer complexes of hypoglycemic sulfonamide with $\pi$-acceptors: Experimental and DFT-TDDFT studies. J. Mol. Struct., 1175, 105-116. https://doi.org/10.1016/j.molstruc.2018.07.074.

22. Fathima, K.S., Sathiyendran, M. \& Anitha, K. (2019). Structure elucidation, biological evaluation and molecular docking studies of 3-aminoquinolinium 2-carboxy benzoate- 
A proton transferred molecular complex. J. Mol. Struct., 1176, 238-248. https://doi.org/10.1016/j.molstruc.2018.08.020.

23. Man, L., Li, T., Wu, X., Lu, K., Yang, L., Liu, X., Yang, Z., Zhou, J. \& Ni, C. (2019). Synthesis, crystal structure, vibrational spectra, nonlinear optical property of an organic charge-transfer compound -4-nitrobenzyl isoquinolinium picrate based on DFT calculations. J. Mol. Struct., 1175, 971-978. https://doi.org/10.1016/j.molstruc.2018.07.054.

24. Refat, M.S., Adam, A.M.A., Saad, H.A., Naglah, A.M. \& Al-Omar, M.A. (2015). transfer-Charge Complexation and Photostability Characteristics of Iodine with bis-1,8-naphthalimide as a Photosensitive Biologically Active Units in Solution and in the Solid State: Linear Correlation of Photostability and Dissociation Energy. Int. J. Electrochem. Sci., 10, 6405-6421.

25. Refat, M.S., Elfalaky, A., Elesh, E., Naglah, A.M. \& Al-Omar, M.A. (2015). Electrical Properties on Charge Transfer Complex of Norfloxacin Drug with Iodine Acceptor. Int. J. Electrochem. Sci., 10, 6433-6443.

26. Naglah, A.M., Al-Omar, M.A., Adam, A.M.A. \& Refat, M.S. (2015). Charge-transfer Complexes Formed between the Sweeteners Saccharin Drug and Acido Acceptors: Structural, Thermal and Morphological Features. Int. J. Pharmacology, 11(8), 929-937. DOI: 10.3923/ijp.2015.929.937.

27. Refat, M.S., Saad, H.A., Eldaroti, H.H., Adam, A.M.A., Al-Omar, M.A. \& Naglah, A.M. (2016). Charge-transfer interactions between nitrogen moieties as a basis for different drugs with a picric acid acceptor. ScienceAsia, 42(6), 397-406. doi: 10.2306/scienceasia1513-1874.2016.42.397.

28. Naglah, A.M., Al-Omar, M.A., Ibrahim, O.B., Refat, M.S., Adam, A.M.A., Saad, H.A. \& El-Metwaly, N.M. (2016). Charge-transfer complexes of two highly efficient drugs with $\sigma-$ and $\pi$-acceptors: Spectroscopic, thermal, and surface morphology characteristics. Russ. J. Gen. Chem., 86(4), 965-974. https://doi.org/10.1134/S1070363216040356.

29. Almalki, A.S.A., Naglah, A.M., Refat, M.S., Hegab, M.S., Adam, A.M.A. \& Al-Omar, M.A. (2017). Liquid and solid-state study of antioxidant quercetin donor and TCNE acceptor interaction: Focusing on solvent affect on the morphological properties. J. Mol. Liq., 233, 292-302. https://doi.org/10.1016/j. molliq.2017.03.033.

30. Arora, S., Kothiyal, N.C., Kumar, R., Shahab, S., Al-Wasidi, A.S., Al-Jafshar, N.M., Al-Otifi, J.S., Naglah, A.M., Refat, M.S., Alghamdi, M.T. \& Adam, A.M.A. (2018). Experimental and Theoretical Studies of Charge Transfer Complex Formed Between the Antibiotic Drug Norfloxacin with Picric Acid: Density Functional Theory Approach. J. Biobased Materials and Bioenergy, 12(2), 203-210. https://doi.org/10.1166/ jbmb.2018.1761.

31. Skoog, D.A. (1985). Principle of Instrumetal Analysis, $3^{\text {rd }}$ edn., Ch. 7, Saunders College Publishing, New York, USA.

32. Harada, I., Tanaka, J. \& Zuno, M.M. (1981). Electronic spectra and structures of polyiodide chain complexes. J. Phys. Chem., 85, 1789-1794. https://doi.org/10.1021/j150613a006.

33. Lever, A.B.P. (1985). Inorganic Electronic Spectroscopy, $2^{\text {nd }}$ ed., Elsevier, Amsterdam, p. 161.

34. Tsubomura, H. \& Lang, R.P. (1961). Molecular Complexes and Their Spectra. XIII. Complexes of Iodine with Amides, Diethyl Sulfide and Diethyl Disulfide. J. Am. Chem. Soc., 83, 2085-2092. https://doi.org/10.1021/ja01470a013.

35. McConnel, H.M., Ham, J.J. \& Platt, J.R. (1964). Regularities in the Spectra of Molecular Complexes. J. Chem. Phys., 21, 66-70. https://doi.org/10.1063/1.1698626.

36. Aloisi, G.G. \& Pignataro, S. (1973). Molecular complexes of substituted thiophens with $\sigma$ and $\pi$ acceptors. Charge transfer spectra and ionization potentials of the donors. J. Chem. Soc., Faraday Trans., 69, 534-539. DOI:10.1039/F19736900534.

37. Foster, R. (1969). Organic Charge Transfer Complexes, Academic Press, London.

38. Wheat, D.C. (1969-1970). Hand Book of Chemistry and Physics, $50^{\text {th }}$ ed.
39. Bellamy, L.J. (1975). The infrared Spectra of Complex Molecules, Chapman \& Hall, London. 